\title{
The Third Asian and Oceanic Congress on Radiation Protection (AOCRP-3)
}

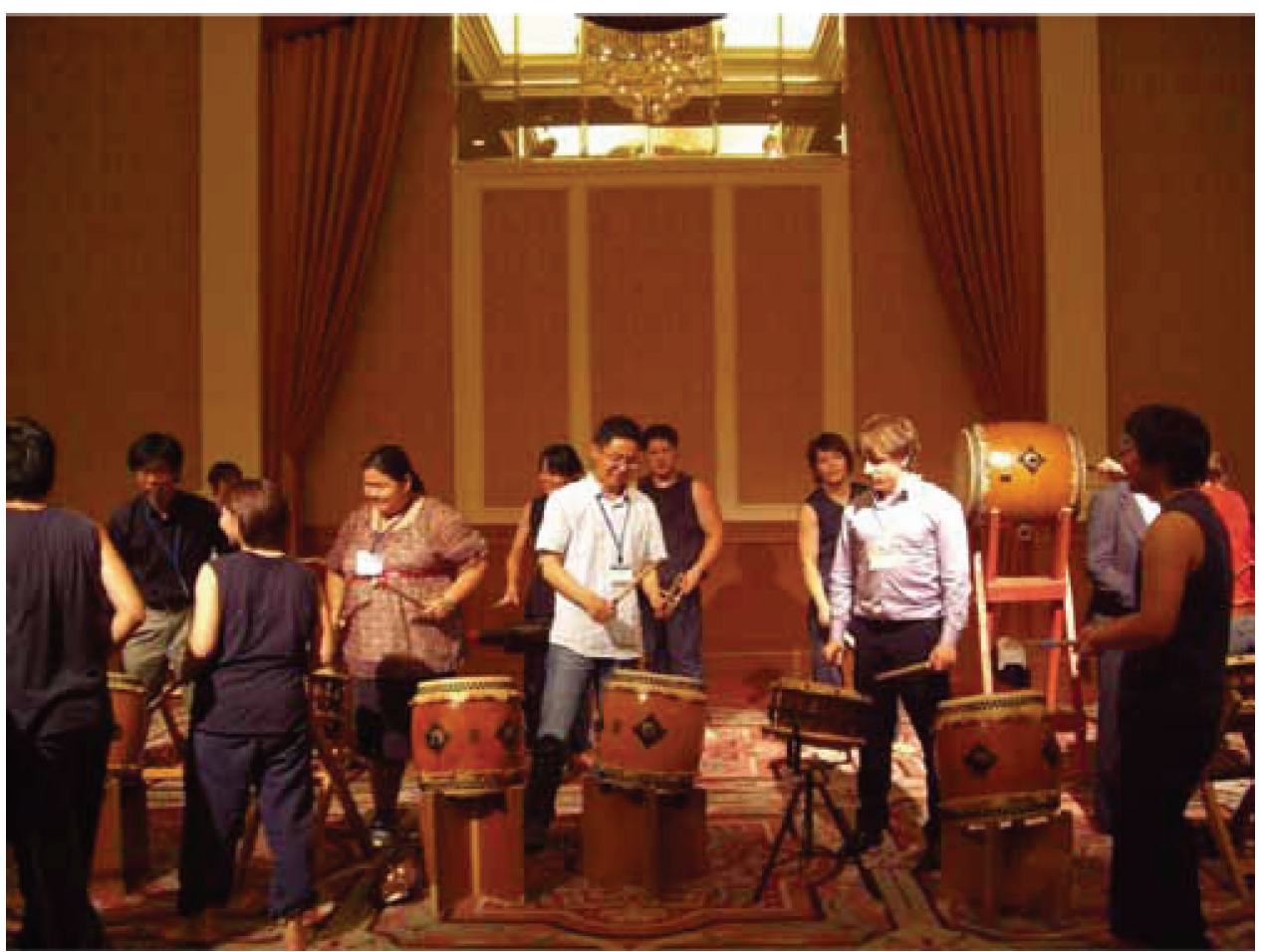

The participants are enjoying to play traditional Japanese drums (Farewell Party)

\section{個人装飾品に含まれる放射性物質一放射能濃度と被ばく線量の検討}

古田 悦子

（253 頁をご覧下さい）

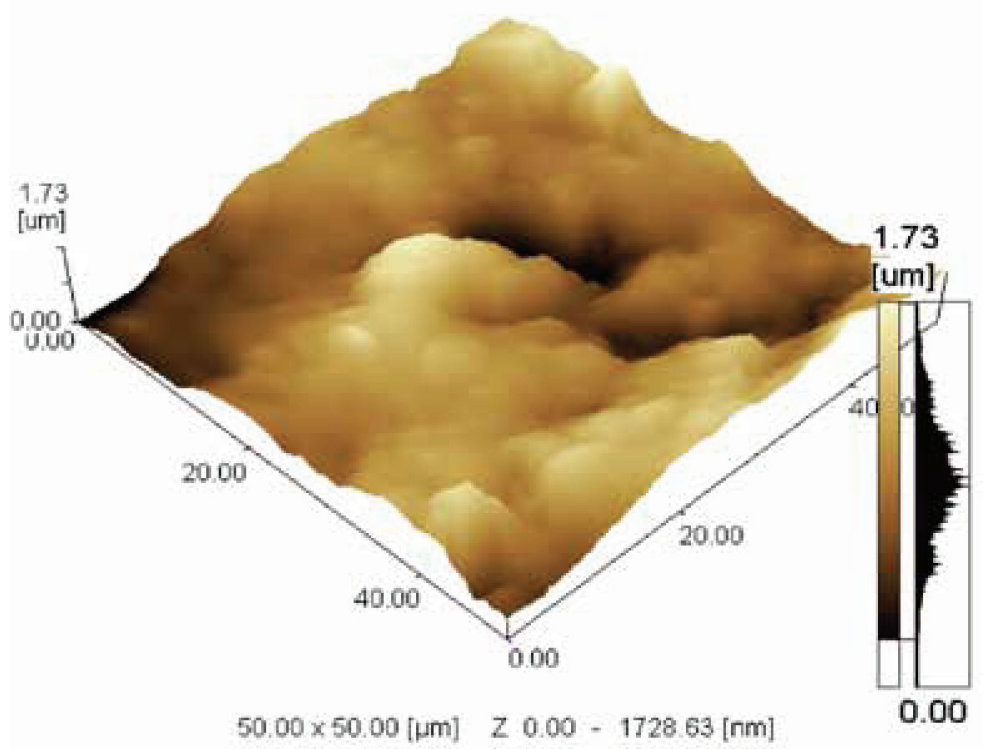

Fig. 1(a) An image of the ceramics surface of the sample No.1 measured by atomic forcemicroscopy.

The ceramics surface is minute unevenness, however, there were no protuberances ofradiation sources on the surface. 